Marquette University

e-Publications@Marquette

Civil and Environmental Engineering Faculty

Research and Publications

Engineering, College of

$1-1-2016$

A Simple Kinetic Analysis of Syngas During Steam Hydrogasification of Biomass Using a Novel Inverted Batch Reactor with Instant High Pressure Feeding

Xin Fan

University of California, Riverside

Zhongzhe Liu

Marquette University, zhongzhe.liu@marquette.edu

Joseph M. Norbeck

University of California, Riverside

Chan S. Park

University of California, Riverside

Accepted version. Bioresource Technology, Vol. 200 (January 2016): 731-737. DOI. (C) 2016 Elsevier Ltd. Used with permission. 


\title{
A Simple Kinetic Analysis of Syngas During Steam Hydrogasification of Biomass Using a Novel Inverted Batch Reactor with Instant High Pressure Feeding
}

\author{
Xin Fan
}

Bourns College of Engineering-Center for Environmental Research and Technology (CE-CERT), Department of Chemical and Environmental Engineering, University of California,

Riverside, $C A$

Zhongzhe Liu

Department of Civil, Construction and Environmental

Engineering, Marquette University,

Milwaukee, WI

Joseph M. Norbeck

Bourns College of Engineering-Center for Environmental Research and Technology (CE-CERT), Department of Chemical and Environmental Engineering, University of California,

Riverside, $C A$ 
NOT THE PUBLISHED VERSION; this is the author's final, peer-reviewed manuscript. The published version may be accessed by following the link in the citation at the bottom of the page.

\author{
Chan S. Park \\ Bourns College of Engineering-Center for Environmental \\ Research and Technology (CE-CERT), Department of Chemical \\ and Environmental Engineering, University of California, \\ Riverside, $C A$
}

\title{
Highlights
}

- Inverted batch reactor with a high pressure feeding system for kinetics study.

- Instant feedstock loading into a hot and pressurized reactor with agitation system.

- The enhanced carbon conversion and char morphology indicated high heating rate.

- Steam hydrogasification of biomass had comparatively lower $\mathrm{CH}_{4}$ activation energy.

\section{Abstract}

A newly designed inverted batch reactor equipped with a pressure-driven feeding system was built for investigating the kinetics of syngas during the steam hydrogasification (SHR) of biomass. The system could instantly load the feedstock into the reactor at high temperature and pressure, which simulated the way to transport the feedstock into a hot and pressurized gasifier. Experiments were conducted from $600^{\circ} \mathrm{C}$ to $700^{\circ} \mathrm{C}$. The inverted reactor showed very high heating rate by enhancing the carbon conversion and syngas production. The kinetic study showed that the rates of $\mathrm{CH}_{4}, \mathrm{CO}$ and $\mathrm{CO}_{2}$ formation during SHR were increased when the gasification temperature went up. SHR had comparatively lower activation energy for $\mathrm{CH}_{4}$ production. The activation energies of $\mathrm{CH}_{4}, \mathrm{CO}$ and $\mathrm{CO}_{2}$ during SHR were $42.8,51.8$ and $14 \mathrm{~kJ} / \mathrm{mol}$, respectively.

Keywords: Kinetics; Synthesis gas; Heating rate; Char; Activation energy

\section{Introduction}

Biomass and biodegradable waste (bio-waste) are a recognized potential source for renewable energy production. Thermochemical processing of biomass and bio-waste can efficiently provide renewable energy with the reduction of greenhouse gas emissions and waste

Bioresource Technology, Vol 200 (January 2016): pg. 731-737. DOI. This article is C Elsevier and permission has been granted for this version to appear in e-Publications@Marquette. Elsevier does not grant permission for this article to be further copied/distributed or hosted elsewhere without the express permission from Elsevier. 
volumes (McKendry, 2002, Ojolo and Bamgboye, 2005 and Pei et al., 2015). Many thermochemical methods in practice have been widely studied, such as combustion, pyrolysis, and gasification (Bridgwater, 2003, Chen et al., 2008, Liu et al., 2010 and Ruth, 1998). In particular, fungible transportation fuels can be synthesized over commercialized catalysts using synthetic gas (syngas) from various gasification technologies. The syngas can also be used for chemical production and power generation. Compared to other thermochemical methods such as fast pyrolysis and catalytic hydropyrolysis, processes which integrate gasification and downstream upgrading units such as methanation and Fischer-Tropsch synthesis have already been commercialized for 30 years (Anastasi, 1980 and Panek and Grasser, 2006). Therefore, gasification is a very competitive processing step for renewable fuel conversion.

Gasification generally uses steam and less oxygen for syngas production (i.e. partial oxidation reaction). The syngas mainly contains $\mathrm{H}_{2}, \mathrm{CO}$ and $\mathrm{CO}_{2}$. When the gasification environment is steam and $\mathrm{H}_{2}$, it is called steam hydrogasification reaction (SHR). The syngas from SHR is rich in $\mathrm{CH}_{4}$. SHR can utilize high moisture feedstock such as green waste and sewage sludge, which normally require drying or dewatering before use or disposal (Brammer and Bridgwater, 1999 and Zhang et al., 2011). SHR can be coupled with steam methane reforming and Fischer-Tropsch synthesis to produce gasoline and diesel with a selfsustainable hydrogen supply. Many related studies were published previously (Jeon et al., 2007, Liu et al., 2013 and Raju et al., 2009).

The knowledge of reliable kinetic data of gasification is valuable and crucial for optimizing the modeling and design of large-scale gasifiers. However, the kinetics of SHR has never been studied systematically by using an appropriate reactor. In general, most labscale kinetic measurements of gasification are conducted based on weight loss in thermogravimetric analyzers at ambient pressure or comparatively slow heating rate (Calvo et al., 2004 and Sun et al., 2009). Though pressurized thermogravimetric analyzer coupled with evolved gas analyzer can be used for volatile component analysis under high pressure, it is costly and still has restrictions on carrier gas. Besides, the sample is usually premade and is initially put in the thermogravimetric analyzer before heating up, which is far from the practical operation that feedstock is fed into a hot reactor. Hence, in

Bioresource Technology, Vol 200 (January 2016): pg. 731-737. DOI. This article is @ Elsevier and permission has been granted for this version to appear in e-Publications@Marquette. Elsevier does not grant permission for this article to be further copied/distributed or hosted elsewhere without the express permission from Elsevier. 
order to obtain reliable kinetic data, designing a reactor configuration which can simulate the way to transport the feedstock into a hot and pressurized reactor with high heating rate is of great interest.

Inspired by many thermochemical conversion studies using atmosphere pressure free fall and drop tube reactors (Wei et al., 2007), an inverted reactor (i.e. inverted impeller in the continuous stirred-tank reactor) associated with an instant high pressure feeding system could be a good option for gasification kinetic study. In addition to instant feeding, the new configuration can be operated under high pressure (preferred by high pressure reaction such as hydrogenation for $\mathrm{CH}_{4}$ formation) and has an impeller to provide better heat and mass transfer as fluidized bed. So the primary goal was to construct this novel reactor and evaluate the kinetics of SHR syngas $\left(\mathrm{CH}_{4}, \mathrm{CO}\right.$ and $\left.\mathrm{CO}_{2}\right)$ at different temperatures. Also, a simplified kinetic model was applied to the complex gasification environment. To the best of our knowledge, the kinetics of biomass gasification in a high pressure feeding reactor was never investigated.

\section{Method}

\subsection{Material}

The pinewood sawdust was used as a biomass waste representative in this study. The proximate analysis (wt\%, as received) showed its moisture, volatile matter, fixed carbon and ash contents were $5.65 \%, 81.52 \%, 12.58 \%$ and $0.25 \%$, respectively. The pinewood sawdust contained $47.56 \%$ carbon, $6.31 \%$ hydrogen, $0.05 \%$ nitrogen, $0.01 \%$ sulfur and $45.81 \%$ oxygen (by difference) on a dry weight basis. The sawdust was ground, sieved to particle size of $0.15-$ $0.18 \mathrm{~mm}$ and dried at 105 for $24 \mathrm{~h}$.

\subsection{Experimental apparatus and methodology}

The schematic diagram of the inverted batch reactor system is shown in Fig. 1(a). The reactor volume was $350 \mathrm{cc}$ (5 cm in diameter and $18 \mathrm{~cm}$ in height). A $\mathrm{K}$ type thermocouple and a pressure transducer were used to measure the inside real-time temperature and pressure. A pressure-driven feeding system was located on the top,

Bioresource Technology, Vol 200 (January 2016): pg. 731-737. DOI. This article is @ Elsevier and permission has been granted for this version to appear in e-Publications@Marquette. Elsevier does not grant permission for this article to be further copied/distributed or hosted elsewhere without the express permission from Elsevier. 
including a feeding tube, two high pressure and temperature steam ball valves and a gas cylinder. The feedstock was stored in the feeding tube and introduced into the reactor by pressure difference. This loading method simulated the feeding to a hot reactor with high heating rate. A thin-wall quartz tube with a fritted porous disc at the bottom was placed inside the vessel. A thin layer of quartz wool was put on the highly perforated disc to hold the sample injected from the top. Gaseous products could pass through the disc easily to leave the reactor (i.e. open test for kinetic study), while the solid residues stayed in the quartz tube. The inverted magnetically controlled impeller was installed at the bottom of the reactor vessel. The continuously stirring six-straight-blade impeller could agitate the inside gas phase and improve the mass and heat transfer. Good agitation performance was confirmed by using a same size flexiglass reactor with dry ice, in which fume was completely mixed. Coolant was used to protect the magnet and condense the escaping steam and tars, which were finally collected by the coalescing filter before entering the following capillary line to the gas analyzer. Additionally, this inverted batch reactor can run closed batch test (i.e. gas outlet closed) and can feed slurry samples. It is flexible for many thermochemical conversion technologies.

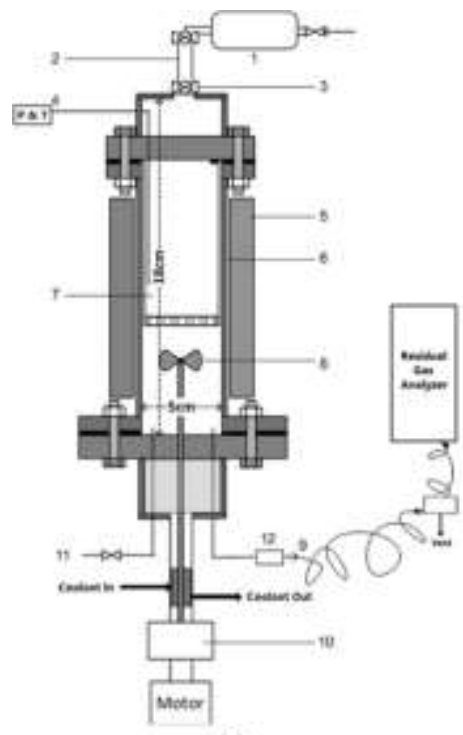

(a)

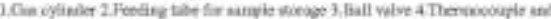

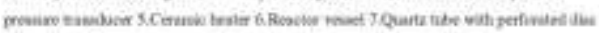

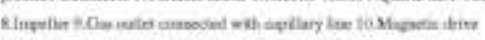

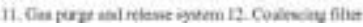

Fig. 1. Inverted batch reactor system (a) Schematic diagram; (b) Temperature and pressure profiles after injection at $700^{\circ} \mathrm{C}$.

Bioresource Technology, Vol 200 (January 2016): pg. 731-737. DOI. This article is @ Elsevier and permission has been granted for this version to appear in e-Publications@Marquette. Elsevier does not grant permission for this article to be further copied/distributed or hosted elsewhere without the express permission from Elsevier. 
NOT THE PUBLISHED VERSION; this is the author's final, peer-reviewed manuscript. The published version may be accessed by following the link in the citation at the bottom of the page.

Experiments were conducted at $600{ }^{\circ} \mathrm{C}, 660^{\circ} \mathrm{C}$ and $700{ }^{\circ} \mathrm{C}$, respectively. $1.5 \mathrm{~g}$ pinewood was mixed with $1.8 \mathrm{~g}$ water and placed in the feeding tube before injection into the heating zone. So the steam to carbon molar ratio was 1.68 . Hydrogen was initially filled in the reactor to 15 psi. Hydrogen was also stored in the gas cylinder on the top and the pressure was adjusted to about 280 psi, 275 psi and 270 psi for each temperature's test. Then the feedstock was instantly injected into the quartz tube along with hydrogen. The inside pressure was suddenly increased to about 210 psi. The hydrogen to carbon molar ratio was calculated to be around 2.4 in the reactor after the injection. The temperature and pressure profiles at $700^{\circ} \mathrm{C}$ are shown in Fig. 1(b). It can be seen that the reactor temperature was well controlled around the set point. The feedstock was sprayed evenly on the quartz wool, which guaranteed good heat transfer.

The permanent gas passed through a long PEEK ${ }^{\mathrm{TM}}$ capillary line (0.0025" inner diameter) purchased from Upchurch Scientific to the residue gas analyzer (MKS-1000 quadruple mass spectrometer). The capillary line controlled the outlet flowrate to the gas analyzer. The loss of product gas was inevitable due to continuous sampling for analysis, but a specific capillary line could minimize the loss. The pressure decrease was about 25 psi within 30 min as shown in Fig. 1(b). The calculated outlet flowrate from the capillary line was about $1.2 \mathrm{cc} / \mathrm{min}$ ( $1 \mathrm{~atm}$ and $25^{\circ} \mathrm{C}$ at the outlet) according to the modified Hagen-Poiseuille equation (Bennett and Myers, 1962 and Liu, 2013). The reactor pressure was used as the capillary line inlet pressure for the flowrate calculation. The analyzer only took in less than $1 \mathrm{cc} / \mathrm{min}$ gas at $1 \mathrm{~atm}$ for real-time composition analysis. The residual gas was vented to the air by a tee fitting, which also guaranteed the inlet pressure of the analyzer at 1 atm.

The real-time intensities of major product gases, $\mathrm{CH}_{4}, \mathrm{CO}$ and $\mathrm{CO}_{2}$, were monitored and normalized to volume percentage using the calibration gas mixture $\left(9.94 \% \mathrm{CH}_{4}, 9.91 \% \mathrm{CO}, 9.9 \% \mathrm{CO}_{2}\right.$ and $70.25 \% \mathrm{H}_{2}$ ). Because $\mathrm{H}_{2}$ was continuously consumed and it was technically difficult to differentiate the produced $\mathrm{H}_{2}$ such as from steam reforming and water gas reaction, the kinetics of $\mathrm{H}_{2}$ production could not be covered in this study. Additionally, due to the overlap at the same atomic mass unit and minor significance relative to major product gas, other hydrocarbons were not identified (O'Hanlon, 2003).

Bioresource Technology, Vol 200 (January 2016): pg. 731-737. DOI. This article is @ Elsevier and permission has been granted for this version to appear in e-Publications@Marquette. Elsevier does not grant permission for this article to be further copied/distributed or hosted elsewhere without the express permission from Elsevier. 
The gas evolution was depicted until the percentage of each syngas component reached the maximum, which was corresponding to the kinetic model described later. The concentrations of these gas components decreased after the peak, which are not shown in the figure.

For the product distribution, the solid residue aforementioned was char. When the inside pressure was close to the room pressure, the gaseous product was almost depleted. Steam and tarry product were condensed and collected by the coalescing filter. The filter was air dried to remove free moisture and the weight increment was the tar yield. The permanent gas (syngas) production was obtained by mass balance on a dry basis. All the tests were conducted in triplicate and the average was shown in the figures.

The morphology of the char collected from $700^{\circ} \mathrm{C}$ kinetic study was investigated in order to confirm the high heating rate of the novel inverted reactor. The morphology was compared with the pinewood and the $700{ }^{\circ} \mathrm{C}$ char obtained from a closed batch experiment with slow heating rate. For this specific comparison experiment, the wet pinewood was located in the reactor at the beginning, and then was heated up at a heating rate of $30^{\circ} \mathrm{C} / \mathrm{min}$ from room temperature to $700{ }^{\circ} \mathrm{C}$ and stayed for $30 \mathrm{~min}$. The gasification condition was similar by keeping similar steam to carbon and hydrogen to carbon molar ratios ( $0.5 \mathrm{~g}$ pinewood and $0.6 \mathrm{~g}$ water with initial 50 psi hydrogen input) and the final reactor pressure was around 210 psi at $700^{\circ} \mathrm{C}$ ). The retention time was $30 \mathrm{~min}$ and then the outlet was open to collect tar and gas. For the morphology analysis, the pinewood sample and two char samples were dried overnight. They were pretreated in a Cressington 108 auto sputter coater and analyzed by scanning electron microscope (SEM) XL30-FEG.

\subsection{Kinetic model}

The thermal decomposition of biomass is a complex process involving a set of concurrent and side reactions. Although many modeling approaches of biomass gasification were proposed previously (Puig-Arnavat et al., 2010), developing a kinetic model for biomass gasification in the presence of both steam and hydrogen was very challenging. Therefore, a simplified first order kinetic model of product

Bioresource Technology, Vol 200 (January 2016): pg. 731-737. DOI. This article is @ Elsevier and permission has been granted for this version to appear in e-Publications@Marquette. Elsevier does not grant permission for this article to be further copied/distributed or hosted elsewhere without the express permission from Elsevier. 
gas formation was applied to SHR (Deng et al., 2009). The model assumed that the biomass decomposed through a series of first-order parallel reactions. Each gas species was generated from an independent, single and molecular reaction with individual activation energy.

The rate of formation of a product gas species and the integration form after the separation of variables are expressed as below.

$r=\frac{d m}{d t}=k\left(m_{0}-m\right)$

$\ln \frac{m_{0}}{m_{0}-m}=k t$

where, $m$ is the amount of gas generated at a given time $t ; m_{0}$ is the maximum amount of a product gas when the release of the gas is completed in the gasification process; $k$ is the rate constant of gas formation; $t$ is reaction time.

According to the integration form, a plot of its left side versus time yields a straight line of which the slope is the value of rate constant $k$.

\section{Results and discussion}

\subsection{Characterization of SHR product}

The effect of temperature on the SHR is presented in Fig. 2. The temperature had strong influence on the product distribution. With the temperature increased from $600^{\circ} \mathrm{C}$ to $700{ }^{\circ} \mathrm{C}$, syngas yield was increased from $43 \%$ to $57 \%$. The char percentage was reduced to below $30 \%$ at $700{ }^{\circ} \mathrm{C}$. Carbon conversion was enhanced due to the higher reactivity of char at higher temperatures. Many previous studies showed similar results that product gas yield and carbon conversion were promoted with the increase of temperature during steam gasification or hydrogasification of carbonaceous materials (Wang et al., 2007 and Wei et al., 2007).

Bioresource Technology, Vol 200 (January 2016): pg. 731-737. DOI. This article is @ Elsevier and permission has been granted for this version to appear in e-Publications@Marquette. Elsevier does not grant permission for this article to be further copied/distributed or hosted elsewhere without the express permission from Elsevier. 


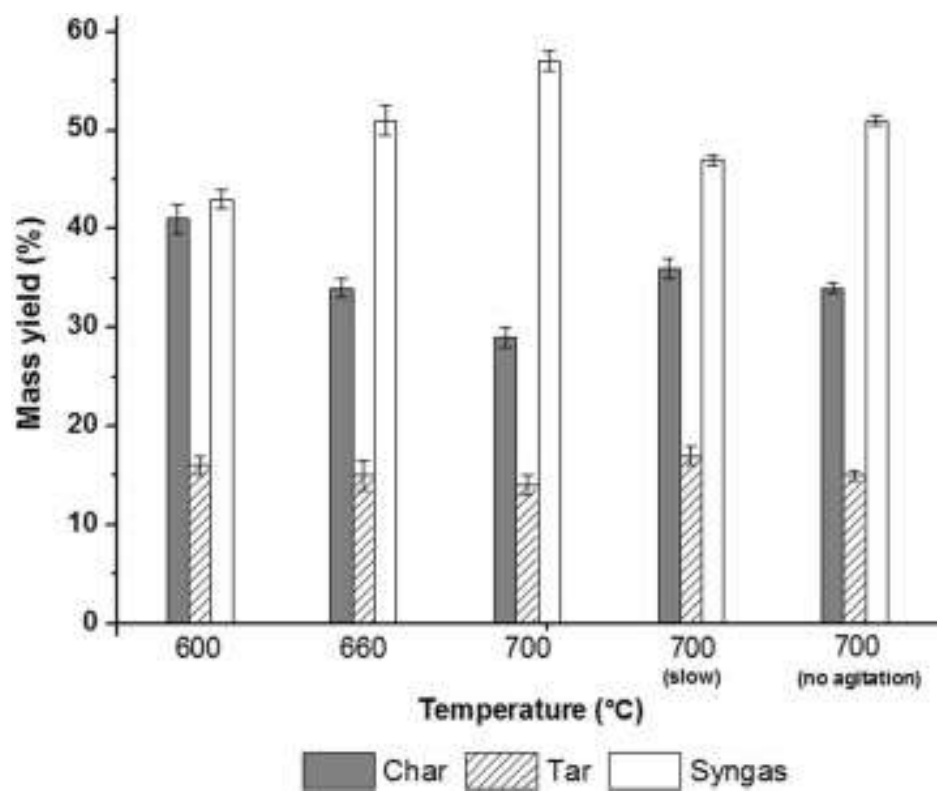

Fig. 2. Product distribution at different temperatures (slow: slow heating rate; no agitation: impeller was off during the test).

Also shown in the figure are the results from the tests with slow heating rate and without using the impeller. When the heating rate was slow, the char yield was above $35 \%$ and the syngas yield was about $10 \%$ lower than that of fast heating rate by instant feedstock loading. In addition, the heating rate could have direct impact on reaction kinetics and higher heating rate could lead to lower activation energy (Fushimi and Araki, 2003). When there was no agitation in the reactor at $700{ }^{\circ} \mathrm{C}$, higher char yield and lower syngas yield can be observed, indicating the impeller played a very important role in enhancing the gas-solid reaction. Therefore, a gasifier such as fluidized bed with better mass and heat transfer is highly preferred for SHR.

The morphology of char can reflect heating rate and char reactivity in the reactor to some extent. SEM images were taken for three different samples: pinewood, char from instant feeding at $700{ }^{\circ} \mathrm{C}$ and char from slow heating to $700{ }^{\circ} \mathrm{C}$. The parent pinewood particle had its original cell structure which was strongly bounded with slits and fractures. The grinding process resulted in the shredded edge. The char from slow heating test showed some destruction and deep opening compared with the original wood cell structure. The char surface was porous but maintained layered rough morphology. These micropore structures were attributed to the devolatilization at low 
temperature (Zanzi et al., 1996). In the case of instant feeding at $700{ }^{\circ} \mathrm{C}$, the char showed a thoroughly deformed structure and the cell structure almost disappeared. In particular, the char had a smooth morphology and signs of melting. The micropore structure shrank or closed, instead, many large cavities showed up. It was due to the fast heating resulting in rapid devotilization and more active sites by forming macropores. The results were in accordance with many studies conducted at high heating rate (Cetin et al., 2005 and Mermoud et al., 2006). The above characterizations indicated that a high heating rate was achieved by using this inverted batch reactor equipped with instant high pressure feeding system.

\subsection{Kinetic analysis of SHR syngas}

The effect of temperature on the formation of $\mathrm{CH}_{4}, \mathrm{CO}$ and $\mathrm{CO}_{2}$ are shown in Fig. 3. $\mathrm{CH}_{4}$ was monotonously increased with the reaction time and the $\mathrm{CH}_{4}$ formation was largely enhanced when the temperature was increased from $600^{\circ} \mathrm{C}$ to $700^{\circ} \mathrm{C}$. The maximum fraction of $\mathrm{CH}_{4}$ at $700{ }^{\circ} \mathrm{C}$ was $4 \%$ after about 30 min. Besides, the $\mathrm{CH}_{4}$ evolution was obviously faster at higher temperature within the first $15 \mathrm{~min}$. As for the formation of CO, similar trends can be seen in Fig. 2(b). The $\mathrm{CO}$ fraction reached the maximum $6 \%$ around $27 \mathrm{~min}$. Compared with $\mathrm{CH}_{4}$ and $\mathrm{CO}$, it took less than $10 \mathrm{~min}$ for $\mathrm{CO}_{2}$ to the peak. The difference was most likely because of the diffusion model. $\mathrm{CH}_{4}$ and $\mathrm{CO}$ could be dominant by chemical reaction (or pore diffusion) during $\mathrm{SHR}$, whereas $\mathrm{CO}_{2}$ was released and controlled by film diffusion (Van Heek and Mühlen, 1991 and Van Heek, 1987).

Bioresource Technology, Vol 200 (January 2016): pg. 731-737. DOI. This article is @ Elsevier and permission has been granted for this version to appear in e-Publications@Marquette. Elsevier does not grant permission for this article to be further copied/distributed or hosted elsewhere without the express permission from Elsevier. 
NOT THE PUBLISHED VERSION; this is the author's final, peer-reviewed manuscript. The published version may be accessed by following the link in the citation at the bottom of the page.

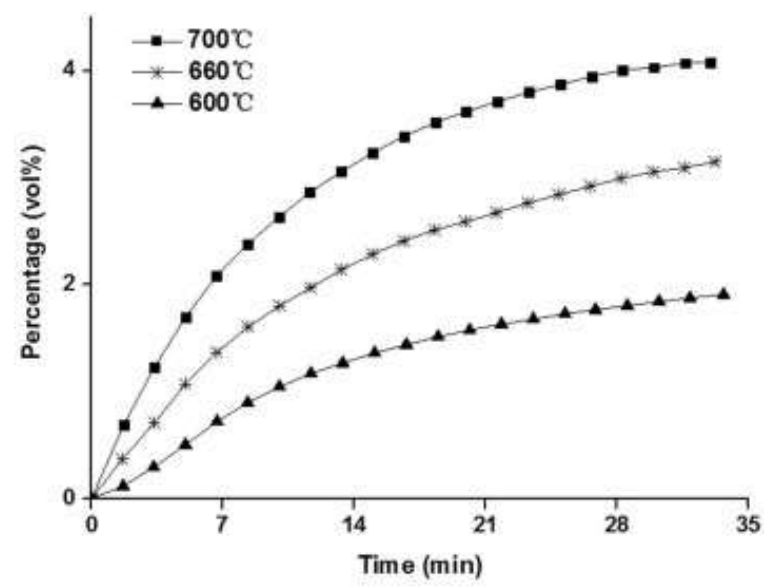

(a) $\mathrm{CH}_{4}$

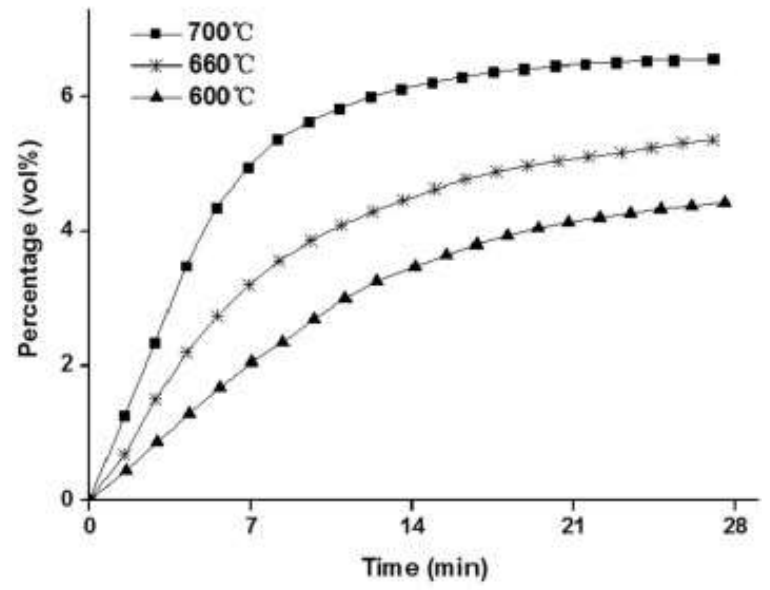

(b) $\mathrm{CO}$

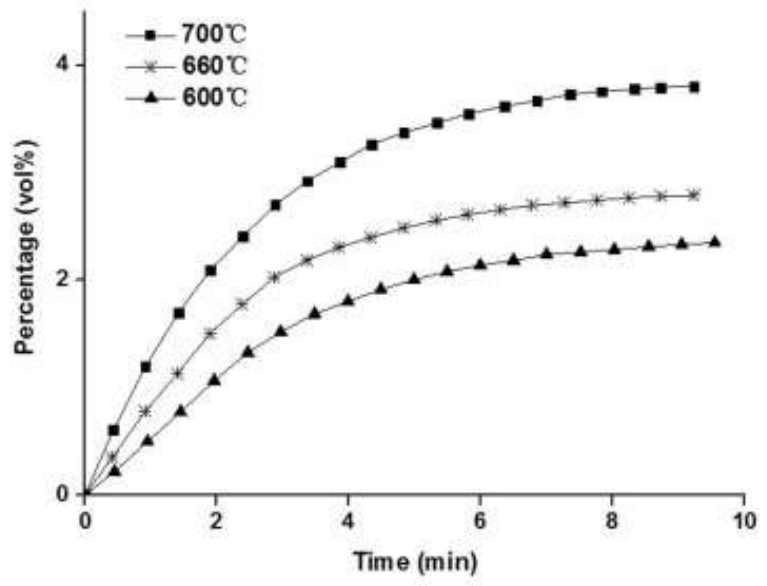

(c) $\mathrm{CO}_{2}$

Fig. 3. Product gas evolutions until reaching the maximum percentage at different temperatures.

Bioresource Technology, Vol 200 (January 2016): pg. 731-737. DOI. This article is @ Elsevier and permission has been granted for this version to appear in e-Publications@Marquette. Elsevier does not grant permission for this article to be further copied/distributed or hosted elsewhere without the express permission from Elsevier. 
NOT THE PUBLISHED VERSION; this is the author's final, peer-reviewed manuscript. The published version may be accessed by following the link in the citation at the bottom of the page.

The kinetic plots of $\ln \left(m_{0} /\left(m_{0}-m\right)\right.$ versus time at different temperatures were derived from the profiles of gas formation and are shown in Fig. 4. The solids lines are least squares analysis results. It can be observed that the experimental data fitted a straight line. The good linear relationship between $\ln \left(m_{0} /\left(m_{0}-m\right)\right.$ and reaction time supported the first-order kinetic rate expression and confirmed the applicability of the model to SHR. Moreover, the slopes of the straight lines became higher as the temperature increased. The slope determined the value of rate constant at a defined temperature. So the higher temperature led to an increase in rate constant. Three gases presented similar results. The correlation coefficients of least squares analysis are shown in Table 1 and the values were up to 0.99. 
NOT THE PUBLISHED VERSION; this is the author's final, peer-reviewed manuscript. The published version may be accessed by following the link in the citation at the bottom of the page.

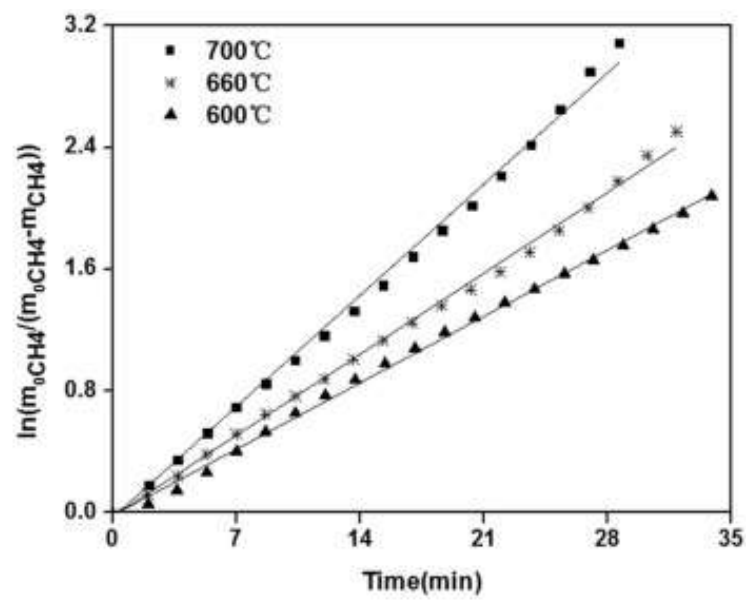

(a) $\mathrm{CH}_{4}$

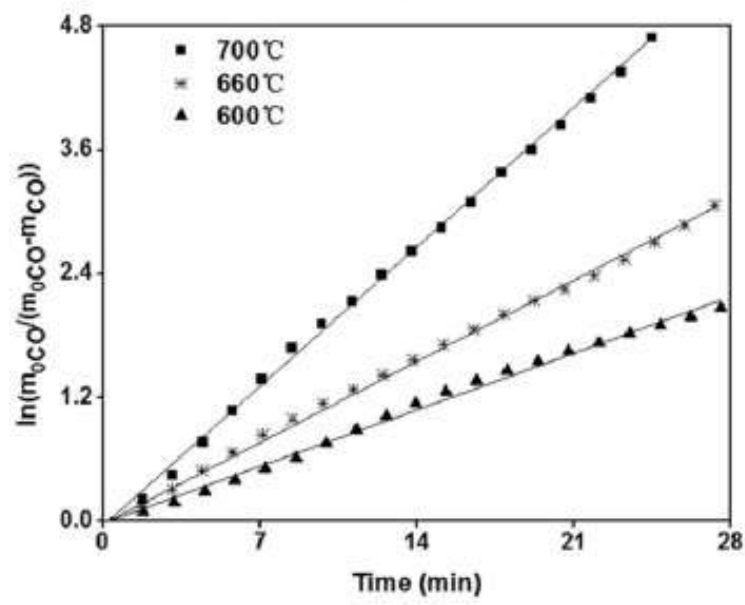

(b) $\mathrm{CO}$

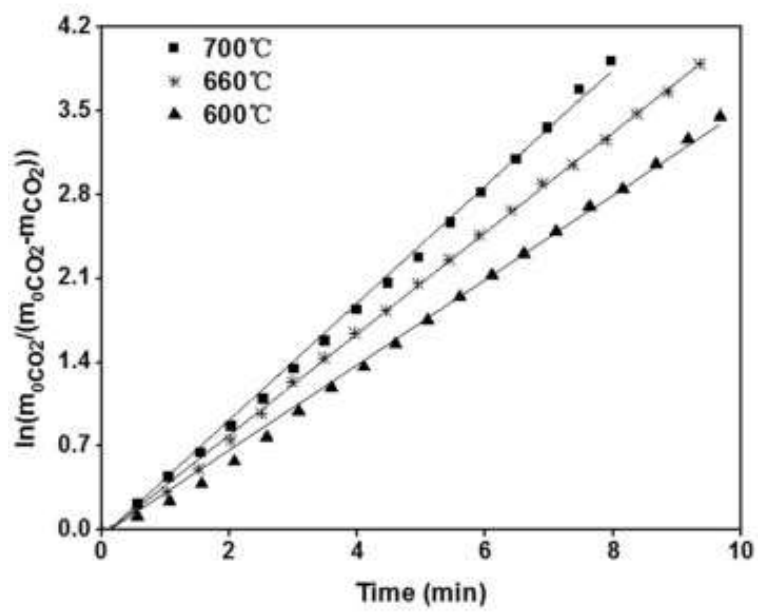

(c) $\mathrm{CO}_{2}$

Fig. 4. Plots of $\ln \left(m_{0} /\left(m_{0}-m\right)\right.$ versus time. granted for this version to appear in e-Publications@Marquette. Elsevier does not grant permission for this article to be further copied/distributed or hosted elsewhere without the express permission from Elsevier. 
NOT THE PUBLISHED VERSION; this is the author's final, peer-reviewed manuscript. The published version may be accessed by following the link in the citation at the bottom of the page.

Table 1. Rate constants of $\mathrm{CH}_{4}, \mathrm{CO}$ and $\mathrm{CO}_{2}$ formation at different temperatures.

$\mathbf{T}\left({ }^{\circ} \mathbf{C}\right)$

Rate constant $\left(\mathrm{min}^{-1}\right)$

Correlation coefficient

600

$\begin{array}{lll}\mathrm{kCH}_{4} & \mathrm{kCO} & \mathrm{kCO}\end{array}$

$\mathrm{kCO}_{2}$

$R^{2} \mathrm{CH}_{4}$

$\boldsymbol{R}^{2} \mathrm{CO}$

$R^{2} \mathrm{CO}_{2}$

660

0.057

0.078

0.381

0.99

0.98

0.99

0.081

0.118

0.429

0.99

0.99

0.99

700

0.105

0.164

0.465

0.99

0.99

0.99

Rate constants of $\mathrm{CH}_{4}, \mathrm{CO}$ and $\mathrm{CO}_{2}$ formation at different temperatures $600{ }^{\circ} \mathrm{C}, 660^{\circ} \mathrm{C}$ and $700{ }^{\circ} \mathrm{C}$ are listed in Table 1 . As aforementioned, the temperature had a positive influence on the rate of product gas formation during $\mathrm{SHR}$. The rates of $\mathrm{CH}_{4}$ and $\mathrm{CO}$ were doubled when the gasification temperature increased from $600{ }^{\circ} \mathrm{C}$ to $700{ }^{\circ} \mathrm{C}$. Thus, for $\mathrm{SHR}, \mathrm{CH}_{4}$ as a key product was favored by higher gasification temperature. The rate of $\mathrm{CO}_{2}$ formation was much higher than the rates of $\mathrm{CO}$ and $\mathrm{CH}_{4}$ formation regardless of the temperatures. It was inferred that the release of $\mathrm{CO}_{2}$ was completed fast at the initial gasification time, which was in agreement with the $\mathrm{CO}_{2}$ evolution profiles.

The activation energy for each gas was calculated based on the Arrhenius equation and the rate constants in Table 1 . The Arrhenius plots of $\mathrm{CH}_{4}, \mathrm{CO}$ and $\mathrm{CO}_{2}$ are shown in Fig. 5. Table 2 shows the calculated activation energies, the Arrhenius pre-exponential factors and the correlation coefficients. Corresponding to the evolution profiles and rate constants, $\mathrm{CO}_{2}$ had the least activation energy while the activation energies of $\mathrm{CH}_{4}$ and $\mathrm{CO}$ were much higher during SHR. The correlation coefficients supported a good linear regression analysis.

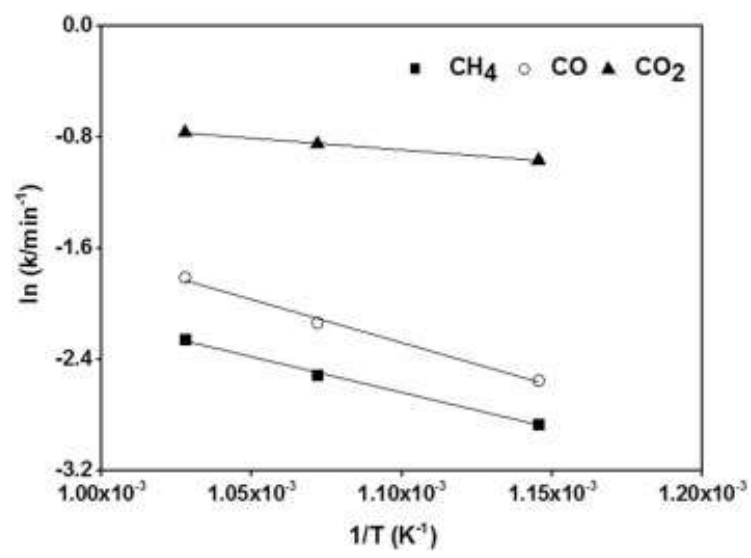

Fig. 5. Arrhenius plots for $\mathrm{CH}_{4}, \mathrm{CO}$ and $\mathrm{CO}_{2}$ formation.

Bioresource Technology, Vol 200 (January 2016): pg. 731-737. DOI. This article is @ Elsevier and permission has been granted for this version to appear in e-Publications@Marquette. Elsevier does not grant permission for this article to be further copied/distributed or hosted elsewhere without the express permission from Elsevier. 
Table 2. Activation energies of $\mathrm{CH}_{4}, \mathrm{CO}$ and $\mathrm{CO}_{2}$ formation.

\begin{tabular}{|c|c|c|c|c|}
\hline Syngas & $\begin{array}{c}\text { Activation } \\
\text { energy } \\
E_{a}(\mathrm{~kJ} / \mathrm{mol})\end{array}$ & $\begin{array}{c}\text { Arrhenius pre-exponential } \\
\text { factor } \\
k_{0}\left(\min ^{-1}\right)\end{array}$ & & $\begin{array}{c}\text { Correlation } \\
\text { coefficient } \\
\boldsymbol{R}^{2}\end{array}$ \\
\hline $\mathrm{CH} 4$ & 42.8 & 20.5 & 0.99 & \\
\hline $\mathrm{CO}$ & 51.8 & 97.1 & 0.98 & \\
\hline $\mathrm{CO} 2$ & 14 & 2.6 & 0.99 & \\
\hline
\end{tabular}

The activation energies were also compared to other works which are presented in Table 3. Because there were very few studies regarding the activation energy of individual syngas component of gasification and most activation energies were calculated using char based on the total, other thermochemical technologies were also included for an overall comparison. It can be seen that even the activation energies of each gas were strongly dependent on the reaction condition and feedstock type, the activation energies of SHR had the same order of magnitude as other works. The activation energy of CO of both SHR and supercritical water gasification was higher compared to most torrefaction and pyrolysis processes, while the activation energies of $\mathrm{CH}_{4}$ and $\mathrm{CO}_{2}$ were obviously lower. The lower activation energies of $\mathrm{CH}_{4}$ and $\mathrm{CO}_{2}$ during gasification were because of the presence of steam and high pressure. Besides, supercritical water gasification had a little bit lower activation energy of $\mathrm{CH}_{4}$ compared to $\mathrm{SHR}$, which was most likely due to the higher pressure of supercritical water gasification (about $25 \mathrm{MPa}$ ). Overall, SHR which combined both steam and hydrogen had comparatively lower activation energy for methane-rich syngas production.

Table 3. The comparison of activation energies.

\begin{tabular}{|c|c|c|c|c|c|c|}
\hline \multirow[t]{2}{*}{ Feedstock } & \multirow{2}{*}{$\begin{array}{c}\text { Range of } \\
\text { temperature } \\
\left({ }^{\circ} \mathrm{C}\right)\end{array}$} & \multicolumn{3}{|c|}{$\begin{array}{c}\text { Activation energy } \\
(\mathrm{kJ} / \mathrm{mol})\end{array}$} & \multirow[t]{2}{*}{ Process } & \multirow[t]{2}{*}{ References } \\
\hline & & $\mathrm{CH}_{4}$ & CO & $\mathrm{CO}_{2}$ & & \\
\hline Pinewood & $600-700$ & 42.8 & 51.8 & 14 & SHR & This work \\
\hline Cellulose & $400-600$ & N/A* & N/A & 15 & \multirow{3}{*}{$\begin{array}{l}\text { Supercritical } \\
\text { water } \\
\text { gasification }\end{array}$} & \multirow{3}{*}{$\begin{array}{l}\text { Guan et al. } \\
\text { (2012), Resende } \\
\text { and Savage } \\
(2009)\end{array}$} \\
\hline Lignin & $500-725$ & 34 & $\mathrm{~N} / \mathrm{A}$ & 15 & & \\
\hline Microalgae & $400-500$ & 40 & N/A & 10 & & \\
\hline Rape stalk & $200-300$ & 89.7 & 44.5 & 20.8 & Torrefaction & Deng et al. (2009 \\
\hline Maize & $400-700$ & 76.7 & 18.98 & N/A & Pyrolysis & $\begin{array}{l}\text { Encinar et al. } \\
\text { (1997) }\end{array}$ \\
\hline
\end{tabular}

Bioresource Technology, Vol 200 (January 2016): pg. 731-737. DOI. This article is @ Elsevier and permission has been granted for this version to appear in e-Publications@Marquette. Elsevier does not grant permission for this article to be further copied/distributed or hosted elsewhere without the express permission from Elsevier. 
NOT THE PUBLISHED VERSION; this is the author's final, peer-reviewed manuscript. The published version may be accessed by following the link in the citation at the bottom of the page.

\begin{tabular}{|c|c|c|c|c|c|c|}
\hline \multirow[t]{2}{*}{ Feedstock } & \multirow{2}{*}{$\begin{array}{c}\text { Range of } \\
\text { temperature } \\
\left({ }^{\circ} \mathrm{C}\right)\end{array}$} & \multicolumn{3}{|c|}{$\begin{array}{c}\text { Activation energy } \\
(\mathrm{kJ} / \mathrm{mol})\end{array}$} & \multirow[t]{2}{*}{ Process } & \multirow[t]{2}{*}{ References } \\
\hline & & $\mathrm{CH}_{4}$ & CO & $\mathrm{CO}_{2}$ & & \\
\hline Pine dust & $600-750$ & 83 & 56 & 32 & & $\begin{array}{l}\text { Bilbao et al. } \\
(1989)\end{array}$ \\
\hline $\begin{array}{l}\text { Cherry } \\
\text { stone }\end{array}$ & $300-800$ & 58.1 & 42.8 & 21.9 & & $\begin{array}{l}\text { González et al. } \\
\text { (2003) }\end{array}$ \\
\hline Artichoke & $400-800$ & 68 & 45 & 21 & & $\begin{array}{l}\text { Encinar et al. } \\
(2009)\end{array}$ \\
\hline
\end{tabular}

\section{Conclusion}

The kinetic analysis of syngas during steam hydrogasification of pinewood was performed from $600{ }^{\circ} \mathrm{C}$ to $700{ }^{\circ} \mathrm{C}$ using an inverted batch reactor equipped with a pressure-driven feeding system. The instant pressure feeding test with high heating rate enhanced the carbon conversion and syngas production compared to the slow heating experiment. The rates of $\mathrm{CH}_{4}, \mathrm{CO}$ and $\mathrm{CO}_{2}$ formation were increased when the gasification temperature went up. SHR had comparatively lower activation energy for $\mathrm{CH}_{4}$ production. The activation energies of $\mathrm{CH}_{4}, \mathrm{CO}$ and $\mathrm{CO}_{2}$ during $\mathrm{SHR}$ were $42.8,51.8$ and $14 \mathrm{~kJ} / \mathrm{mol}$, respectively.

\section{References}

Anastasi, 1980. J. Anastasi. Sasol: South Africa's oil from coal storybackground for environmental assessment. TRW Environmental Engineering Div, Redondo Beach, CA, USA (1980).

Bennett and Myers, 1962. C. Bennett, J. Myers. Momentum, Heat, and Mass transfer. (third ed.) McGraw-Hill (1962).

Bilbao et al., 1989. R. Bilbao, A. Millera, J. Arauzo. Kinetics of weight loss by thermal decomposition of xylan and lignin. Influence of experimental conditions. Thermochim. Acta, 143 (1989), pp. 137-148.

Brammer and Bridgwater, 1999. J. Brammer, A. Bridgwater. Drying technologies for an integrated gasification bio-energy plant. Renew. Sust. Energ. Rev., 3 (4) (1999), pp. 243-289.

Bridgwater, 2003. A. Bridgwater. Renewable fuels and chemicals by thermal processing of biomass. Chem. Eng. J., 91 (2-3) (2003), pp. 87-102.

Calvo et al., 2004. L. Calvo, M. Sánchez, A. Morán, A. García. TG-MS as a technique for a better monitoring of the pyrolysis, gasification and

Bioresource Technology, Vol 200 (January 2016): pg. 731-737. DOI. This article is @ Elsevier and permission has been granted for this version to appear in e-Publications@Marquette. Elsevier does not grant permission for this article to be further copied/distributed or hosted elsewhere without the express permission from Elsevier. 
combustion of two kinds of sewage sludge. J. Therm. Anal. Calorim., 78 (2) (2004), pp. 587-598.

Cetin et al., 2005. E. Cetin, R. Gupta, B. Moghtaderi. Effect of pyrolysis pressure and heating rate on radiata pine char structure and apparent gasification reactivity. Fuel, 84 (10) (2005), pp. 1328-1334.

Chen et al., 2008. D. Chen, Y. Yu, H. Zhu, Z. Liu, Y. Xu. Ferrite process of electroplating sludge and enrichment of copper by hydrothermal reaction. Sep. Purif. Technol., 62 (2) (2008), pp. 297-303

Deng et al., 2009. J. Deng, G. Wang, J. Kuang, Y. Zhang, Y. Luo. Pretreatment of agricultural residues for co-gasification via torrefaction. J. Anal. Appl. Pyrol., 86 (2) (2009), pp. 331-337.

Encinar et al., 1997. J. Encinar, F. Beltrán, J. González, M. Moreno. Pyrolysis of maize, sunflower, grape and tobacco residues. J. Chem. Technol. Biotechnol., 70 (4) (1997), pp. 400-410

Encinar et al., 2009. J. Encinar, J. Gonzalez, G. Martínez, S. Román. Jerusalem artichoke pyrolysis: energetic evaluation. J. Anal. Appl. Pyrol., 85 (1-2) (2009), pp. 294-300.

Fushimi and Araki, 2003. C. Fushimi, K. Araki. Effect of heating rate on steam gasification of biomass. 2. Thermogravimetric-mass spectrometric (TG-MS) analysis of gas evolution. Ind. Eng. Chem. Res., 42 (17) (2003), pp. 3929-3936.

González et al., 2003. J. González, J. Encinar, J. Canito. Pyrolysis of cherry stones: energy uses of the different fractions and kinetic study. $J$. Anal. Appl. Pyrol., 67 (1) (2003), pp. 165-190.

Guan et al., 2012. Q. Guan, P. Savage, C. Wei. Gasification of alga Nannochloropsis sp. in supercritical water. J. Supercrit. Fluids, 61 (2012), pp. 139-145.

Jeon et al., 2007. S. Jeon, C. Park, C. Hackett, J. Norbeck. Characteristics of steam hydrogasification of wood using a micro-batch reactor. Fuel, 86 (17-18) (2007), pp. 2817-2823.

Liu, 2013. Liu, Z., 2013. Development of a Sorption Enhanced Steam Hydrogasification Process for In-situ Carbon Dioxide $\left(\mathrm{CO}_{2}\right)$ Removal and Enhanced Synthetic Fuel Production (Ph.D. thesis). University of California, Riverside.

Liu et al., 2010. Z. Liu, G. Qian, Y. Sun, R. Xu, J. Zhou, Y. Xu. Speciation evolutions of heavy metals during the sewage sludge incineration in a laboratory scale incinerator. Energy Fuels, 24 (4) (2010), pp. 24702478.

Liu et al., 2013. Z. Liu, C. Park, J. Norbeck. Sorption enhanced steam hydrogasification of coal for synthesis gas production with in-situ $\mathrm{CO}_{2}$ removal and self-sustained hydrogen supply. Int. J. Hydrogen Energy, 38 (17) (2013), pp. 7016-7025.

Bioresource Technology, Vol 200 (January 2016): pg. 731-737. DOI. This article is @ Elsevier and permission has been granted for this version to appear in e-Publications@Marquette. Elsevier does not grant permission for this article to be further copied/distributed or hosted elsewhere without the express permission from Elsevier 
NOT THE PUBLISHED VERSION; this is the author's final, peer-reviewed manuscript. The published version may be

accessed by following the link in the citation at the bottom of the page.

McKendry, 2002. P. McKendry. Energy production from biomass (part 2): conversion technologies. Bioresour. Technol., 83 (1) (2002), pp. 4754.

Mermoud et al., 2006. F. Mermoud, S. Salvador, L. Steene, F. Vande Golfier. Influence of the pyrolysis heating rate on the steam gasification rate of large wood char particles. Fuel, 85 (10-11) (2006), pp. 1473-1482.

O'Hanlon, 2003. J. O'Hanlon. A User's Guide to Vacuum Technology. (third ed.) John Wiley \& Sons (2003).

Ojolo and Bamgboye, 2005. S. Ojolo, A. Bamgboye. Thermochemical conversion of municipal solid waste to produce fuel and reduce waste. Agric. Eng. Int., 7 (2005), pp. 1-8.

Panek and Grasser, 2006. J. Panek, J. Grasser. Practical Experience Gained During The First Twenty Years Of Operation Of The Great Plains Gasification Plant And Implications For Future Projects. US Department of Energy-Office of Fossil Energy, Washington (2006).

Pei et al., 2015. P. Pei, K. Ling, J. He, Z. Liu. Shale gas reservoir treatment by a $\mathrm{CO}_{2}$-based technology. J. Nat. Gas Sci. Eng. (2015). http://dx.doi.org/10.1016/j.jngse.2015.03.026

Puig-Arnavat et al., 2010. M. Puig-Arnavat, J. Bruno, A. Coronas. Review and analysis of biomass gasification models. Renew. Sust. Energ. Rev., 14 (9) (2010), pp. 2841-2851.

Raju et al., 2009. A. Raju, C. Park, J. Norbeck. Synthesis gas production using steam hydrogasification and steam reforming. Fuel Process. Technol., 90 (2) (2009), pp. 330-336.

Resende and Savage, 2009. F. Resende, P. Savage. Expanded and updated results for supercritical water gasification of cellulose and lignin in metal-free reactors. Energy Fuels, 23 (12) (2009), pp. 6213-6221.

Ruth, 1998. L. Ruth. Energy from municipal solid waste: a comparison with coal combustion technology. Prog. Energy Combust. Sci., 24 (6) (1998), pp. 545-564.

Sun et al., 2009. Y. Sun, R. Xu, Z. Liu, J. Zhou, G. Qian. Comparison of thermochemical properties of anaerobic digested sludge and undigested sludge by TG-MS. Acta Sci. Circumstantiae, 29 (1) (2009), pp. 169-174.

Van Heek, 1987. K. Van Heek. Progress in the kinetics of coal and char gasification. Chem. Eng. Technol., 10 (1) (1987), pp. 411-419.

Van Heek and Mühlen, 1991. K. Van Heek, H. Mühlen. Chemical kinetics of carbon and char gasification. Fundamental Issues in Control of Carbon Gasification Reactivity, Springer, Netherlands (1991), pp. 1-34.

Wang et al., 2007. S. Wang, H. Baek, H. Jang. Hydrogasification of various carbonaceous sources using pressure change properties. Korean $\mathrm{J}$. Chem. Eng., 24 (3) (2007), pp. 532-536.

Bioresource Technology, Vol 200 (January 2016): pg. 731-737. DOI. This article is @ Elsevier and permission has been granted for this version to appear in e-Publications@Marquette. Elsevier does not grant permission for this article to be further copied/distributed or hosted elsewhere without the express permission from Elsevier 
NOT THE PUBLISHED VERSION; this is the author's final, peer-reviewed manuscript. The published version may be accessed by following the link in the citation at the bottom of the page.

Wei et al., 2007. L. Wei, S. Xu, L. Zhang, C. Liu, H. Zhu, S. Liu. Steam gasification of biomass for hydrogen-rich gas in a free-fall reactor. Int. J. Hydrogen Energy, 32 (1) (2007), pp. 24-31.

Zanzi et al., 1996. R. Zanzi, K. Sjöström, E. Björnbom. Rapid hightemperature pyrolysis of biomass in a free-fall reactor. Fuel, 75 (5) (1996), pp. 545-550.

Zhang et al., 2011. G. Zhang, H. Wang, Y. Xu, Z. Liu, G. Xu. Enhanced improvement of sludge dewaterbility by municipal solid waste incineration(MSWI) fly ash. Fresen. Environ. Bull., 20 (5) (2011), pp. 1236-1244.

Corresponding author. Tel.: +1 626320 2965; fax: +1 414288

6149. 
NOT THE PUBLISHED VERSION; this is the author's final, peer-reviewed manuscript. The published version may be accessed by following the link in the citation at the bottom of the page.

\section{Appendix A. Supplementary data}
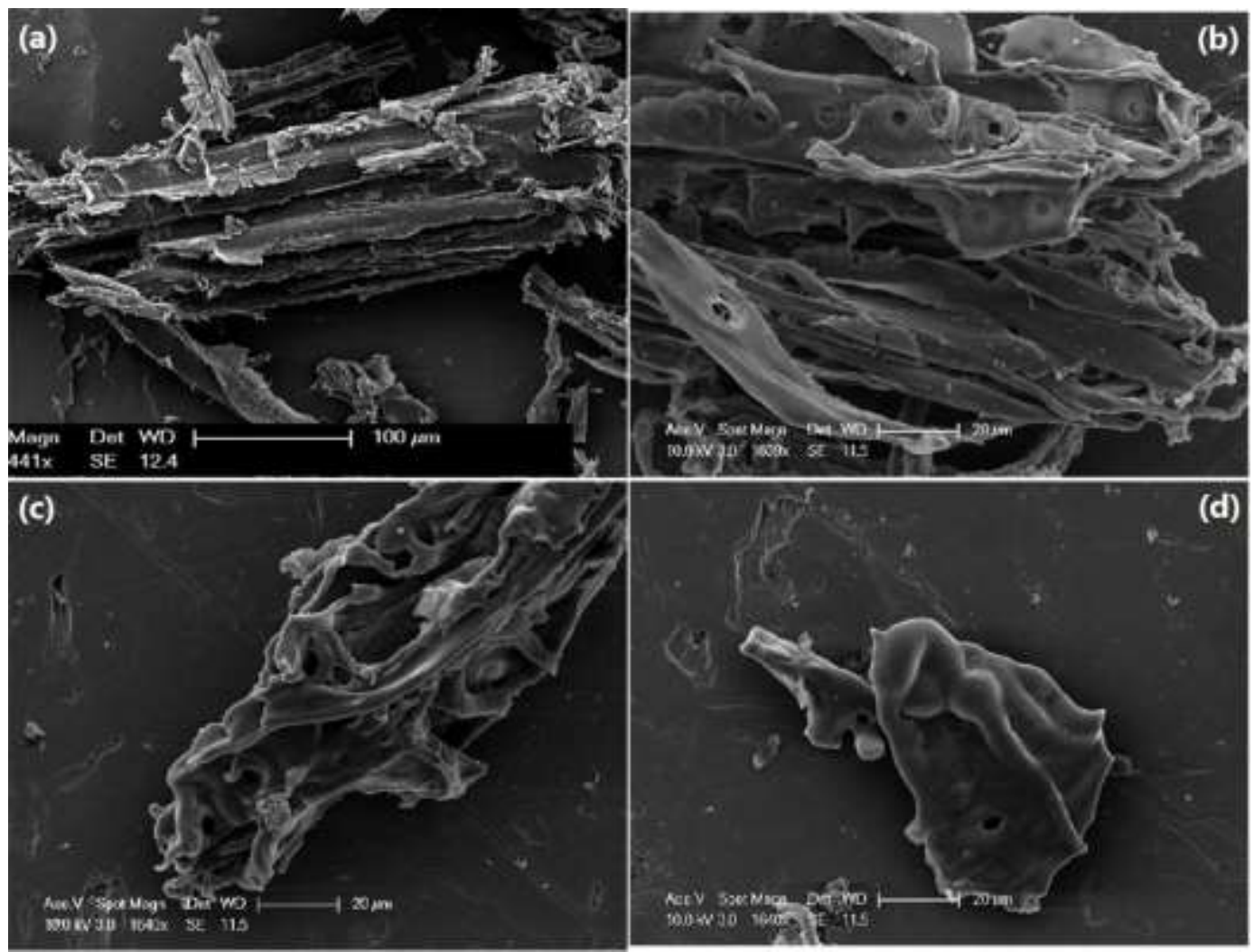

Fig.S1 SEM images of (a) Pinewood, (b) Char from slow heating, (c)-(d) Char from instant feeding 